American Periodicals, 2007, v17, n2, pages 245-259.

ISSN: (print 1054-7479), (online 1548-4238)

http://muse.jhu.edu/journals/amp/

http://muse.jhu.edu/journals/american_periodicals/v017/17.2robb.html

(C) 2007 The Ohio State University Press

\title{
WINSOR MCCAY, GEORGE RANDOLPH CHESTER, AND THE TALE OF THE JUNGLE IMPS
}

\section{Jenny E. Robb}

In 2006 Lucy Shelton Caswell, the curator of the Ohio State University Cartoon Research Library, received a call from a local businesswoman who wanted to bring in some old cartoon drawings that she had found. The Library does not provide appraisal or authentication services, so Caswell attempted to direct her elsewhere. The woman was very persistent, however, so Caswell agreed to see her the next day. The woman walked in with a shabby, portfolio-sized cardboard box from which she produced eleven large hand-colored drawings that Caswell was astonished to discover were original comic strips by Winsor McCay. McCay is considered one of the greatest comic strip artists of all time, a master and pioneer of the art form. Caswell was particularly surprised, because these drawings were from McCay's very first newspaper comic strip series, A Tale of the Jungle Imps. Until then, no Jungle Imps originals were known to have survived from an era when comics were considered ephemera: something to be enjoyed today and then discarded tomorrow. For the most part, original comic strips were not collected or preserved by museums, libraries or collectors, and although some artists saved their originals, most were destroyed or disappeared. Somehow these eleven had survived and had found their way to the Cartoon Research Library.

\section{The Tale of the Jungle Imps}

The tale of the Jungle Imps begins in early January of 1903, when the Cincinnati Enquirer began running advertisements to announce a new and exciting feature: "Comic Pictures in Colors." The ads read:

THE SUNDAY ENQUIRER has long been pre-eminent in the field of contemporary journalism. All that is best and latest in news, fiction, rhyme and story has been laid before its votaries with lavish and unstinted hand. Notwithstanding these facts, the issue for SUNDAY, JANUARY 18 will mark the beginning of a new era in ENQUIRER history. On that date it will present to its reader a splendid new supplement containing the

\section{COMIC PICTURES IN COLORS.}

This supplement will become a permanent feature of the SUNDAY ENQUIRER and will be in addition to its usual pages of news and special matter. $^{1}$

With this enhancement, the Enquirer followed the lead of the eastern newspapers, which had introduced Sunday comics and begun experimenting with color in the mid-1890s, first to compete with the popular humor weeklies, but soon also to compete with each other. The early evolution of the newspaper comic strip was largely shaped by the fierce circulation wars between New York publishing magnates Joseph Pulitzer, William Randolph Hearst, and James Gordon Bennett, Jr. Although color comics had been featured in Sunday supplements previously, Pulitzer's New York World contributed the 
most famous example when it colored Richard Felton Outcault's comics featuring Mickey Dugan. Mickey's nightshirt was made yellow, and he was henceforth known as "The Yellow Kid." In 1896, Hearst lured Outcault and his Yellow Kid to the New York Journal's new full-color Sunday comic supplement in an effort to gain the edge over his main rival, Pulitzer's World. The popularity and success of these early efforts encouraged smaller papers around the country to follow suit. The Enquirer, founded in 1848, printed 40,000 copies a day by $1900 .^{2}$ It featured its first Sunday comics in black and white on June $8,1902 .^{3}$

The advertisement for its new Sunday supplement went on to explain what Enquirer readers would find in the new feature:

The Katzenjammer Kids, Happy Hooligan, Foxy Grandpa (copyright, 1903, W.R. Hearst) and all the other old favorites of ENQUIRER readers will appear in gay garb, together with a series of new and original comics which is sure to please "children of all ages" from seven to seventy.

The newspaper also promised pages devoted to the latest fashions, illustrated articles, and "bright and interesting stories for the little folks."

As pledged, the new era of color comics in the Enquirer began on January 18, 1903. Carl Schultze's Foxy Grandpa and Jimmy Swinnerton's Mount Ararat appeared on the front page of the new supplement in color. The back page of the eight-page supplement included Rudolph Dirks's Katzenjammer Kids and Frederick Opper's Happy Hooligan. In addition to these syndicated comic strips, the newspaper also featured on its third page a full-page color comic created exclusively for the Enquirer. It was the first in a series known as A Tale of the Jungle Imps. This comic feature was a partnership between two relatively unknown newspapermen who would both later become famous for their individual contributions to the periodical press and as pioneers in the nascent moving picture industry. George Randolph Chester wrote the rhymes for the Jungle Imps under the pseudonym "Felix Fiddle," while Winsor McCay provided the artwork, signing his creations "Winsor Mc."

The two men would have been about the same age when they collaborated on the Jungle Imps, although the exact dates and places of their births are elusive. Chester was probably born in 1869 , in either Indiana, Ohio, or Kentucky. ${ }^{5}$ McCay's grave marker indicates that he was also born in 1869, although his biographer thinks that 1867 is more likely. ${ }^{6}$ McCay's parents lived in Michigan at the time, but census records show that he was born in Canada, when his mother was visiting her family.

Before settling in Cincinnati, both Chester and McCay had moved to different cities in the Midwest in search of better opportunities. Chester married Elizabeth Rothermel on July 25, 1895 in Davenport, Iowa, where their first son, George R. Chester Jr. was born in $1896 .^{7}$ Chester reportedly held a number of unrelated jobs, including cook, waiter, plumber, paperhanger, and pen-and-ink artist, before joining the staff of the Detroit News as a reporter. ${ }^{8}$ In 1901 he took a job at the Cincinnati Enquirer and was quickly promoted to Sunday editor. ${ }^{9}$

When he was nineteen, McCay left Spring Grove, Michigan, to attend business school in Ypsilanti. Preferring art to business, he spent most of his time learning drawing techniques from a local Ypsilanti professor, John Goodison, and stealing away to Detroit 
to draw portraits of patrons at Wonderland, a kind of dime museum. McCay moved on to Chicago in 1889, where he worked for a printing firm that specialized in advertising for traveling circuses and other shows. In 1891 he moved again, this time to Cincinnati. There he found employment producing signs and posters for Kohl and Middleton's Vine Street Dime Museum, which exhibited curiosities and "freaks" such as a two-headed calf, "Joe-Joe the dog-faced boy," and the "Wild Man of Afghanistan." In 1891 McCay married Maud Dufour, and their first child, Robert Winsor McCay, was born in 1896 (the same year Chester's first child was born). Two years later, McCay took a job at the Cincinnati Commercial Tribune; he then joined the Cincinnati Enquirer shortly before Chester in $1900 .{ }^{10}$

In 1903 the two men teamed up to create the original comic A Tale of the Jungle Imps for the Enquirer's new Sunday color supplement. The Jungle Imps spoofed Rudyard Kipling's Just So Stories, which had been published the year before. Kipling's stories were written in prose, but concluded with a rhyming poem. Each story explained the origin of an exotic animal's curious feature or of a human achievement, such as "How the Whale got his Throat," "How the Rhinoceros got his Skin," "How the Leopard Got His Spots," and "How the Alphabet was Made." Similarly, the Jungle Imps featured fanciful stories describing how particular animals acquired their most distinguishing features. In each weekly installment, a different animal is made miserable by the constant teasing and torture it endures at the hands of three Jungle Imps: Boo-boo, Gack, and Hickey. The distressed animal seeks aid from a group of wise monkeys, who transform the animal into its present familiar form, enabling it to defend itself. The animal gets revenge on the Imps in the end and is rid of their torment forever. The only human in the comic, Felix Fiddle, is an old man with a tall hat and long white beard who carries a red umbrella and a suitcase. He does not take an active in role in the events; rather, he appears as a bystander passively looking on in each panel, allowing nature to take its course uninterrupted by human interference. The strip also satirizes Darwin's theory of evolution, with the imps and the monkeys representing the natural forces that cause species to evolve.

The Jungle Imps format differed slightly from other comic strips at the time, which led McCay scholar John Canemaker to call it a "proto comic-strip."11 By 1903 most newspaper strips featured a series of sequential panels with text in captions or speech balloons (or both). The Jungle Imps' narrative, however, was told through a combination of rhyming verse illustrated by sequential panels. Poetry and humorous verse were common in newspapers and magazines of the time. McCay did experiment with speech balloons in May and June of 1903, but then abandoned them.

The depiction of the Imps is particularly offensive and racist to modern sensibilities. They are drawn as half-dressed black characters with big earrings and stereotypical facial features that many cartoonists during this era used to represent black people. In this regard, the strip is very much a product of its time. Early newspaper and magazine comic pages are filled with similar racist portrayals of blacks and other minorities, reflecting the reality of what was considered acceptable at the time. As the villains in the stories, the Imps are not so much evil as cruelly and carelessly mischievous. In "Fourth of July in the Jungle," Chester writes, "They just couldn't help being mean-like your little cousins." In one episode, "How the Booby Bird Got Even," Grandpa Imp appears and disciplines the three young imps for their tricks. 
It is impossible to know how popular A Tale of the Jungle Imps was with its Cincinnati readers, but it lasted for forty-three weekly installments, a relatively long run for comic titles at the time. At least one attempt was made by Chester at merchandising his co-creation. An advertisement in the Cincinnati Enquirer on November 22, 1903 touted "The Song of the Jungle Imps" sheet music "By Felix Fiddle" with "Music by Virgil M. Gerrard." Readers were encouraged to ask their "music dealer or send 25 cents to Gerrard-Chester Music Co., Cincinnati, Ohio." The ad featured drawings of Felix Fiddle and an Imp.

In October of that year, Winsor McCay accepted a job in New York from James Gordon Bennett Jr., publisher of the New York Herald. The last Jungle Imps ran on November 18, 1903, after McCay was already working in New York. The next week, Felix Fiddle was back with a new strip called The Clown Folks, which depicted a family of clowns with mischievous children and a wiener dog. The new offering was drawn by Apthorp “Ap" Adams, a friend of McCay's, and featured a largely unimaginative panel layout with traditional captions.

\section{On to Fame and Fortune}

McCay went on to create innovative and popular comic strips such as Henry Henrietta, Little Sammy Sneeze, Dream of a Rarebit Fiend, and Pilgrim's Progress for the New York Herald. His masterpiece, Little Nemo in Slumberland, debuted in the Herald on October 15, 1905. In 1907 the Jungle Imps reappeared as residents of Candy Island in Little Nemo. The main characters-Little Nemo, the Princess of Slumber-land, and Flip_-visit the Chief of the jungle, who takes them to his palace. They ride on an elevator lifted up by a huge snake and in an automobile powered by goats. As the characters leave Candy Island, the Imps try to steal Flip, who instead kidnaps one of them. This Imp, later called Impie, becomes a regular character in the strip, causing mischief throughout Nemo's many adventures.

McCay also made a name for himself on the vaudeville circuit, with a popular chalk-talk featuring the characters from his comic strips. Starting in 1906, he regularly performed in New York and around the country, while still producing comic strips and other illustrations for the newspaper. A lavish Broadway musical based on Little Nemo was produced in 1908 and was reported to have cost $\$ 300,000$ for its New York run, an enormous sum compared to the standard $\$ 30,000-\$ 40,000$ of productions at the time. ${ }^{12}$

In 1911 McCay was lured into the Hearst family, where he continued Little Nemo in Slumberland under the new title In the Land of Wonderful Dreams. Although he hoped the move would provide him more freedom to pursue his varied artistic interests, the opposite was the case. Hearst wanted him to focus on serious editorial cartoons and gradually forced McCay to give up his comic strips and vaudeville performances. ${ }^{13}$ McCay's editorial cartoons, while showcasing his exquisite draftsmanship, generally lacked the spirit and liveliness of his comics.

After McCay's departure from the Cincinnati Enquirer, Chester continued to write short stories for the paper, which like most daily newspapers of that era included fiction in addition to news and feature stories. A second son, Robert Fey Chester, was born around 1904. In 1906, Chester broke into the thriving magazine market and soon after left the Enquirer. A prolific writer, his stories appeared in major magazines of the 
day such as McClure 's, Cosmopolitan, Collier's and the Saturday Evening Post. The star of his most successful series, J. R.Wallingford, was a likable ne'er-do-well who traveled from town to town swindling money from gullible people. Chester's Wallingford stories were collected and published as books and, like McCay's Little Nemo, were adapted to the stage as a Broadway musical in $1910 .{ }^{14}$ The U.S. Census of 1910 indicates that Chester had obtained a level of financial success; the family had three live-in servants, a butler, a maid, and a cook at its home in Cincinnati.

In that year, Chester moved to New York, where he caused something of a scandal that ended in divorce. He had left his wife in Cincinnati "to attend to selling the house and winding up the affairs at home." ${ }^{\prime 5}$ However, his wife's closest friend, Lillian De Rimo moved to New York shortly after Chester, and the two were living in the same hotel. After arriving in New York, Mrs. Chester sued for divorce in 1911, naming De Rimo in the suit. Later that year, Chester wed De Rimo in Paris, although there was some question as to the legality of the marriage because they did not wait for the final divorce decree. ${ }^{16}$ A month later, Chester's first wife received the final decree and custody of their two children. ${ }^{17}$ In addition to being a romantic union, Chester's second marriage was also a working partnership. The two collaborated and are listed as co-authors on many of Chester's stories and books after 1911. In 1915, Chester told a New York Times reporter, "You know, Mrs. Chester and I work together; we go fifty-fifty on the Wallingford stories and all the rest of the work." 18

During the 1910s, the professional careers of Chester and McCay crossed once again in New York - this time in the field of motion pictures, which had been invented around the same time as the newspaper comic strip. With considerable success and acclaim, McCay had begun experimenting with animation to enhance his vaudeville act. Animation was in its infancy at the time and was quite a novelty. In 1911 he produced a short film version of the act called "Winsor McCay, the Famous Cartoonist of the N.Y Herald and His Moving Comics." The film featured McCay as himself and silent film star John Bunny, as well as animated versions of Little Nemo characters drawn by McCay. The live-action portions were filmed at the Vitagraph Company of America, a studio founded in Manhattan by cartoonist J. Stuart Blackton. At the time, the flourishing and prolific company had film studios in Brooklyn and Hollywood. McCay's animation drawings were photographed at Vitagraph's Brooklyn studio, which was located near McCay's home in Sheepshead Bay. McCay went on to create other animated shorts, including The Story of a Mosquito (1912), Gertie the Dinosaur (1914) and The Sinking of the Lusitania (1918). The design for the mosquito in The Story of the Mosquito is based on the one McCay drew for the Jungle Imps of June 14, 1903, titled "How the Mosquito Got His Bill."

Starting in 1913, Chester and his wife also turned their attention to the burgeoning film industry, receiving writing and editing credits on dozens of silent films over the next decade. Most were made by Vitagraph, the same studio that produced McCay's animated films. In 1915 a series of movies based on Chester's popular Wallingford stories was produced by Wharton Studios and distributed by Pathé Exchange (connected to William Randolph Hearst). The series was called The New Adventures of J. Rufus Wallingford, and the cast included a young Oliver Hardy, who would later achieve fame as half of the duo Laurel and Hardy. The Chesters later wrote a Wallingford movie for Vitagraph, titled Son of Wallingford, which Chester himself directed. It was released in 1921, the same 
year that another Wallingford movie, Get-Rich-Quick Wallingford, was produced by Cosmopolitan Productions. ${ }^{19} 1921$ also saw the release of Black Beauty, which the Chesters adapted to film for Vitagraph.

Canemaker wrote of McCay, "Many of the people he met throughout his career remained lifelong friends." ${ }^{20}$ It seems that Chester was no exception. In the early 1920s, Chester and McCay conceived of a new collaborative project: "an ambitious animated film about the history of the world according to the Bible." McCay reportedly asked for a two-year leave of absence to make the film, but Hearst rejected his request. ${ }^{21}$ McCay's contract with Hearst expired in 1924, but on February 26 of that year, Chester died suddenly of a heart attack in New York. McCay and former Cincinnati Enquirer colleague Ap Adams both attended Chester's funeral and appeared in a photograph of the funeral procession. ${ }^{22}$ Adams, still a close friend of McCay, had also moved to New York and had assisted McCay with his animation.

Except for a brief and relatively unsuccessful attempt to revive Little Nemo for the Herald-Tribune Syndicate, McCay spent the rest of his life drawing editorial cartoons for Hearst. He died on July 26, 1934.

\section{The Tale Continues}

Over 100 years after A Tale of the Jungle Imps was published, eleven originals from the series resurfaced in Columbus. They were brought to the Cartoon Research Library by the woman who discovered them in her family's shop, where they had been sitting for decades in a stack with other old items. The pieces had been acquired by her grandfather, but she did not know how or why. Her father recalled his own father, who founded the business, telling him that there were some valuable things in the stack, so he had kept them all these years. The business was closing and there was some talk of getting rid of the old cartoons, but, fortunately, the family decided to see if they were worth anything first. As luck would have it, the works were discovered in Columbus, the only city in the United States with an academic research library devoted entirely to printed cartoon and comic art and, oddly, a city with no known connection to McCay (except for the fact that the Cartoon Research Library has the largest public collection of McCay's work). The Library was able to acquire five of the eleven originals, thanks to the generosity of the family, who wishes to remain anonymous.

The items were in remarkably good shape, although some conservation was deemed necessary. The comic strip had been drawn on paper mounted on a thick, acidic backing board that had turned brittle and could damage the artwork if it cracked. Plus, there was some soiling and staining on the objects, along with some damaged or missing corners. The Ohio State University Libraries' conservator, Harry Campbell, was brought in. First, the objects were "dry cleaned" using erasers and brushes to remove smudging and soiling from the surface. The backing boards were separated from the surface paper by lifting them apart with a spatula, then gently scraping the remaining board and adhesive residue off the back of the drawing. The backing boards were saved and stored separately. One had been used, presumably by McCay, as a pallet for mixing watercolors. Next, using a vacuum pump and solvents with water, Campbell pulled stains from mold, animal droppings, and water through the back of the paper onto a blotter below. The drawings were then lined with a heavy Japanese paper affixed with wheat starch paste (all 
reversible procedures), which served to strengthen the paper support and to "fill in" the missing corners. The filled areas were "toned," or painted with water colors to blend better with the color of the immediately adjacent area. The filled areas remain distinguishable from the original portion, but they are less distracting. Also, minor inpainting filled in small areas where the black ink had been lost.

Unlike the originals from his other comic strips, all eleven of the found Jungle Imps were fully and beautifully hand-colored with watercolor. Chester's poems were pasted on to complete the design. A comparison of the originals to the printed tearsheets suggests that the ink drawings were photographed before the watercolor was applied in order to produce the printing plate for the black lines and text. McCay may then have hand-colored the drawings to serve as a guide for the printer, who would have made the color plates for the halftone color printing process. Full color was achieved by four-color separation, named so because a separate plate is used for each primary color and one for black. Combinations of the primary colors produced the various shades required. McCay probably spent the extra time necessary to paint the originals because the color printing process was new to him and to the Enquirer's printers. Although not exactly identical, the tearsheets show that the printers followed the coloring on the drawings very closely. Originals of McCay's later strips also demonstrate that he was very concerned with their color schemes and would communicate his wishes by writing notes to the printer or indicating the color that an area should be in blue pencil, which would not reproduce when photographed. In Masters of American Comics, John Carlin writes, "McCay was also a master colorist who used shading and tone to strengthen and unify the effect of his lines. . . . Few cartoonists have cared as much (or had as much control) as McCay did about how his black-and-white drawings were printed in color." 23

Another interesting and unusual feature is a small drawing of Felix Fiddle in the lower corner of "How the Quillypig Got His Quills." The drawing is crossed out and replaced with another drawing to the right of the first. McCay rarely made mistakes or corrections and was known for requiring very little in the way of preliminary pencil sketching before moving to the final inking stage. But the Quillypig, published on January 25, 1903, was only the second Jungle Imps. It appears McCay did not leave enough space for Felix Fiddle's tall hat in the first version that he crossed out and replaced.

Many signature features of McCay's style can be seen in his first attempt at a comic strip series. The characteristic thick black outline of characters and objects in the foreground is present, along with his impressive ability to render animals of all shapes and sizes. McCay is celebrated for his extraordinary page compositions and innovative use of panels, which reached an apex in Little Nemo. Not surprisingly, these early efforts feature creative and beautifully-designed panel layouts that complement the animals and action. In fact, no two page layouts in the series are exactly same. McCay's fascination with metamorphosis and motion can also be seen here, anticipating his accomplishments in animation. Looking back with the benefit of hindsight, we can see that McCay's genius as a master of the comic strip and animation art forms is foreshadowed in these remarkable examples of the Jungle Imps.

The five Jungle Imps complement the Cartoon Research Library's extensive holdings of Winsor McCay materials, most of which are part of the Woody Gelman Collection, the John Canemaker Collection, and the San Francisco Academy of Comic 
Art Collection. Holdings that include more than 75 originals and more than 1000 tearsheets of McCay's comic strips and editorial cartoons chronicle his entire career. Also included are original Gertie the Dinosaur animation drawings, a Little Nemo sheet music cover, and copies of McCay correspondence, diaries, and other manuscript material. A printed Union List of work by McCay and related materials at the Cartoon Research Library is available upon request. The San Francisco Academy of Comic Art Collection finding aid is available online at the Cartoon Research Library's website: http://cartoons.osu.edu.

\section{NOTES}

1. Cincinnati Enquirer, January 10, 1903, 4.

2. Graydon DeCamp, The Grand Old Lady of Vine Street: The Cincinnati Enquirer (Cincinnati: The Merten Co., 1991), 105

3. DeCamp The Grand Old Lady of Vine Street, 162.

4. Cincinnati Enquirer, January 10, 1903, 4.

5. Herbert Corey, writing in Cosmopolitan (May 1911), reported that an interviewer once asked Chester where he was born and received the response, "I really don't care. Do you prefer any particular city?," before claiming Richmond, Indiana. Chester's obituary in the Cincinnati Enquirer (February 27, 1924) lists his birth place as Cincinnati, but the U.S. Census records of 1900 and 1910 indicate that it was Kentucky. In 1869 , Kentucky did not require birth records to be collected or recorded on either a state or county level, so that claim is impossible to verify. The 1920 Census lists his birthplace as Ohio, but that of his mother as Kentucky.

6. John Canemaker, Winsor McCay: His Life and Art (New York: Harry N. Abrams, 2005). McCay himself gave 1871 as the correct year on more than one occasion.

7. Chester's obituary in the Cincinnati Enquirer (February 27, 1924) gives her maiden name as Bethermel; Census records of 1880 and 1900 indicate her name was Rothermel and she was the daughter of Adam and Mary Rothermel of Indiana. See also "Mrs. Geo. R. Chester Gets Final Decree," New York Times, December 3, 1911, 18.

8. Herbert Corey, "The Author of 'Wallingford," Cosmopolitan Magazine, May 1911, 790-791.

9. Martha G. Bower, "George Randolph Chester," Dictionary of Literary Biography: American Short Story Writers 1880-1910, ed. Bobby Ellen Kimbel (Detroit: Gale Research Inc., 1989), 78:85.

10. Canemaker, Winsor McCay, 28-57.

11. Canemaker, Winsor McCay, 60.

12. Canemaker, Winsor McCay, 148.

13. Canemaker, Winsor McCay, 181.

14. Bower, "George Randolph Chester," 87.

15. "Mrs. Geo. R. Chester Gets Final Decree."

16. "Novelist Chester Remarried Too Soon," New York Times, November 2, 1911, 6.

17. "Mrs. Geo. R. Chester Gets Final Decree."

18. Joyce Kilmer, "Americans Like to be Fooled," New York Times, June 6, 1915, SM19.

19. Jimmy Durante starred as Wallingford's assistant "Schnozzle" in the last film adaptation of the Wallingford stories, New Adventures of Get-Rick-Quick Wallingford, produced by MGM and released in 1931 (Mordaunt Hall, “The Screen; An Artful Swindler. ..," New York Times, October 10, 1931).

20. Canemaker, Winsor McCay, 40.

21. Canemaker, 198.

22. Canemaker, Winsor McCay, 185.

23. John Carlin, et. al., Masters of American Comics (New Haven: Yale University Press, 2005), 37. 


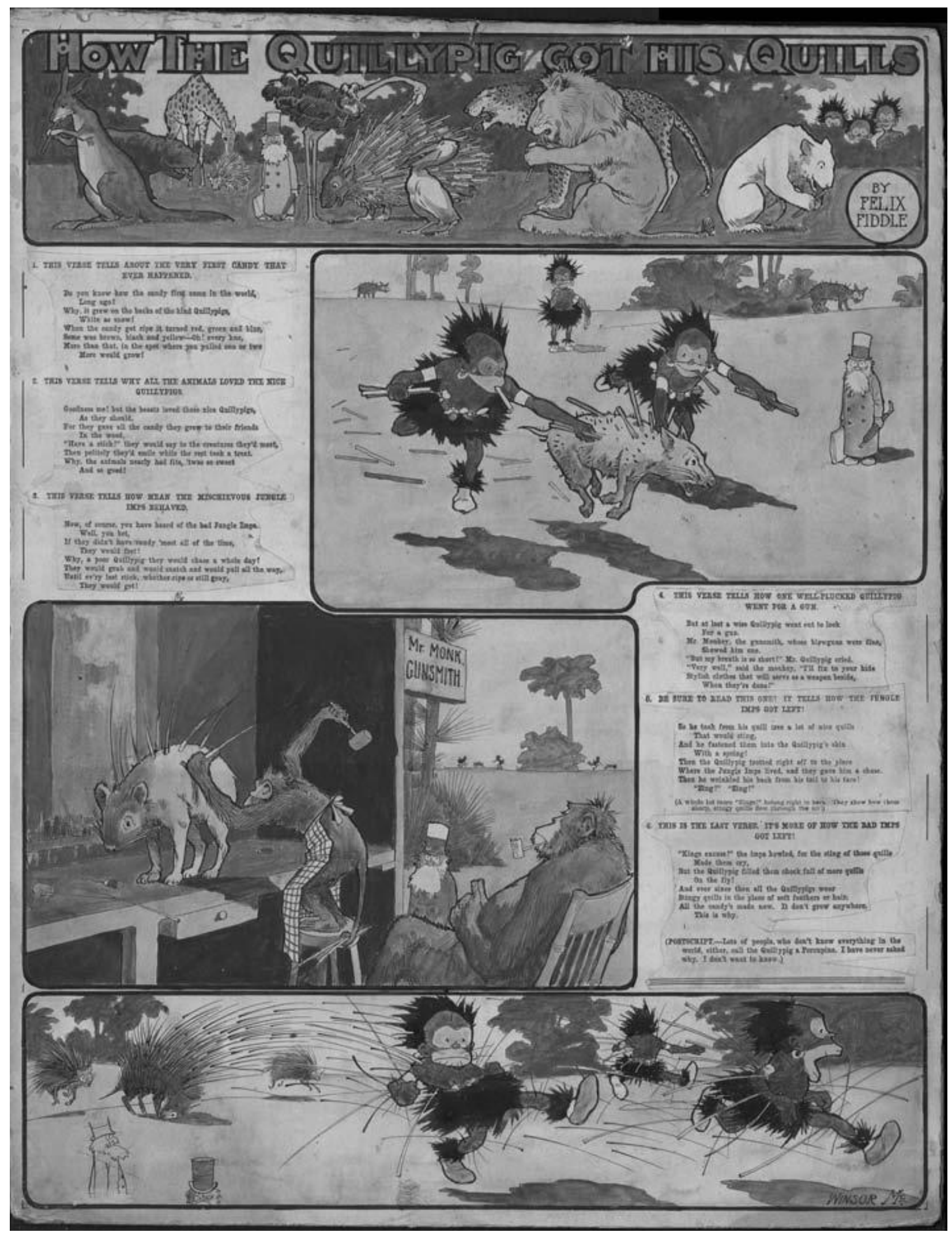




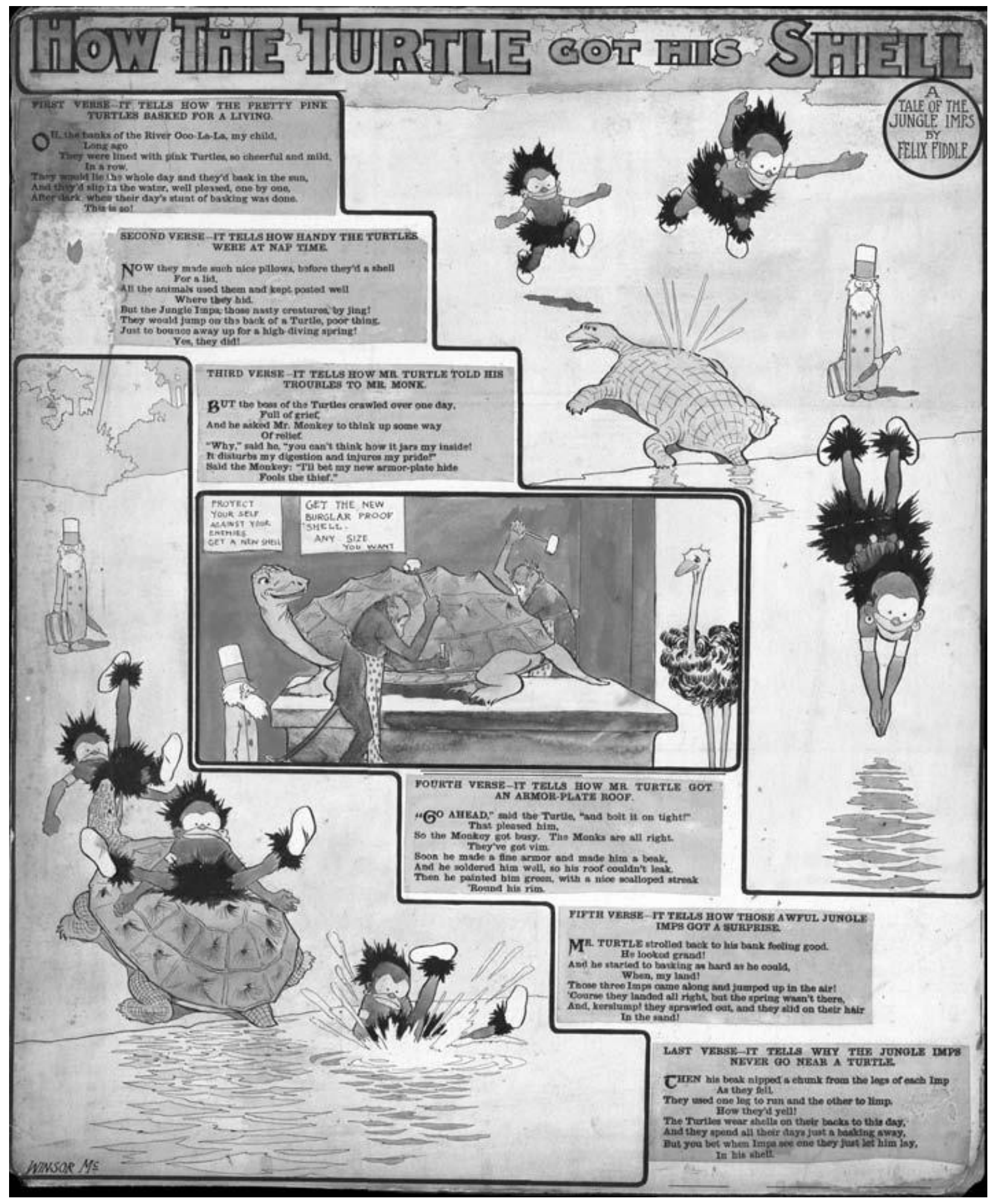




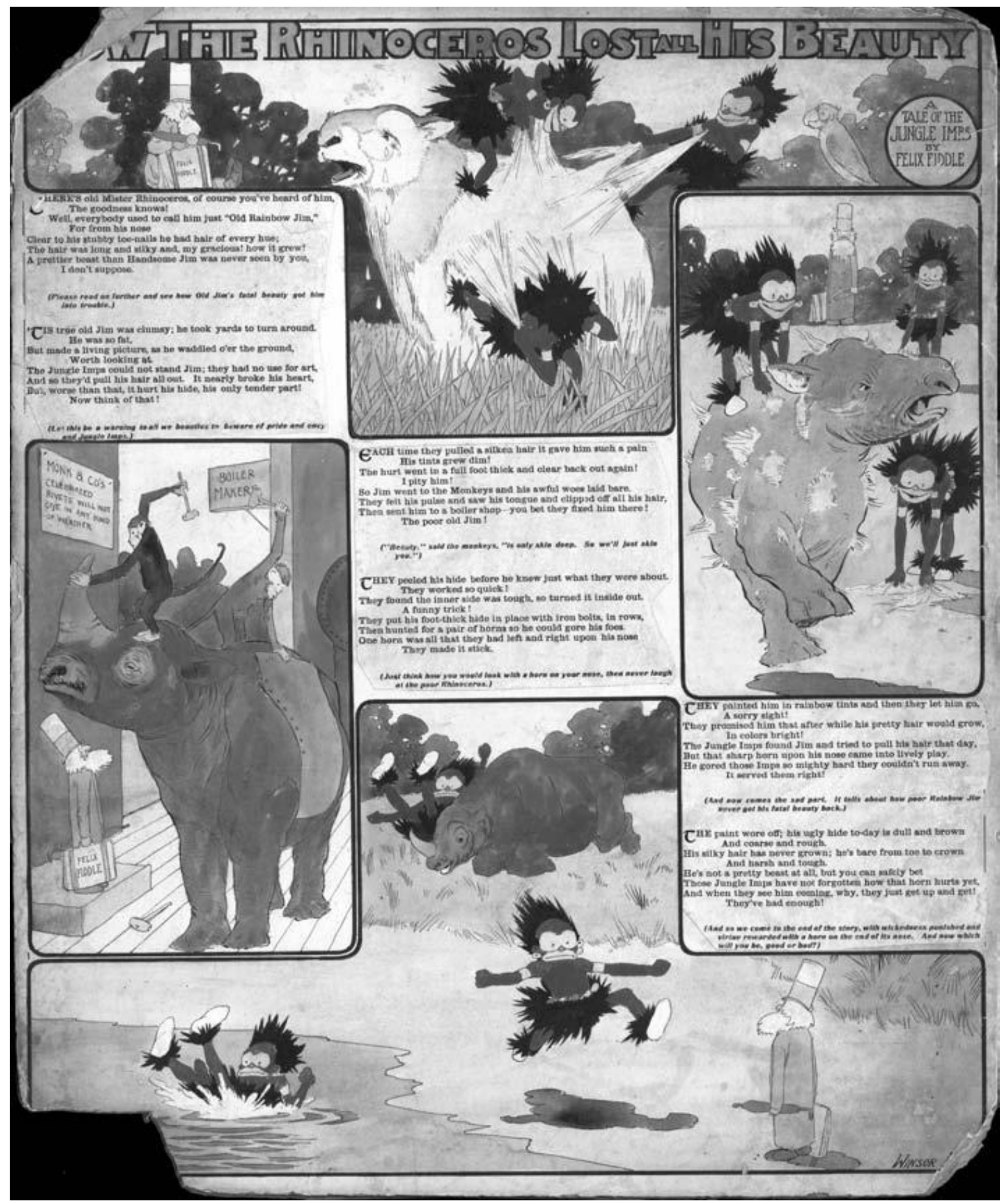




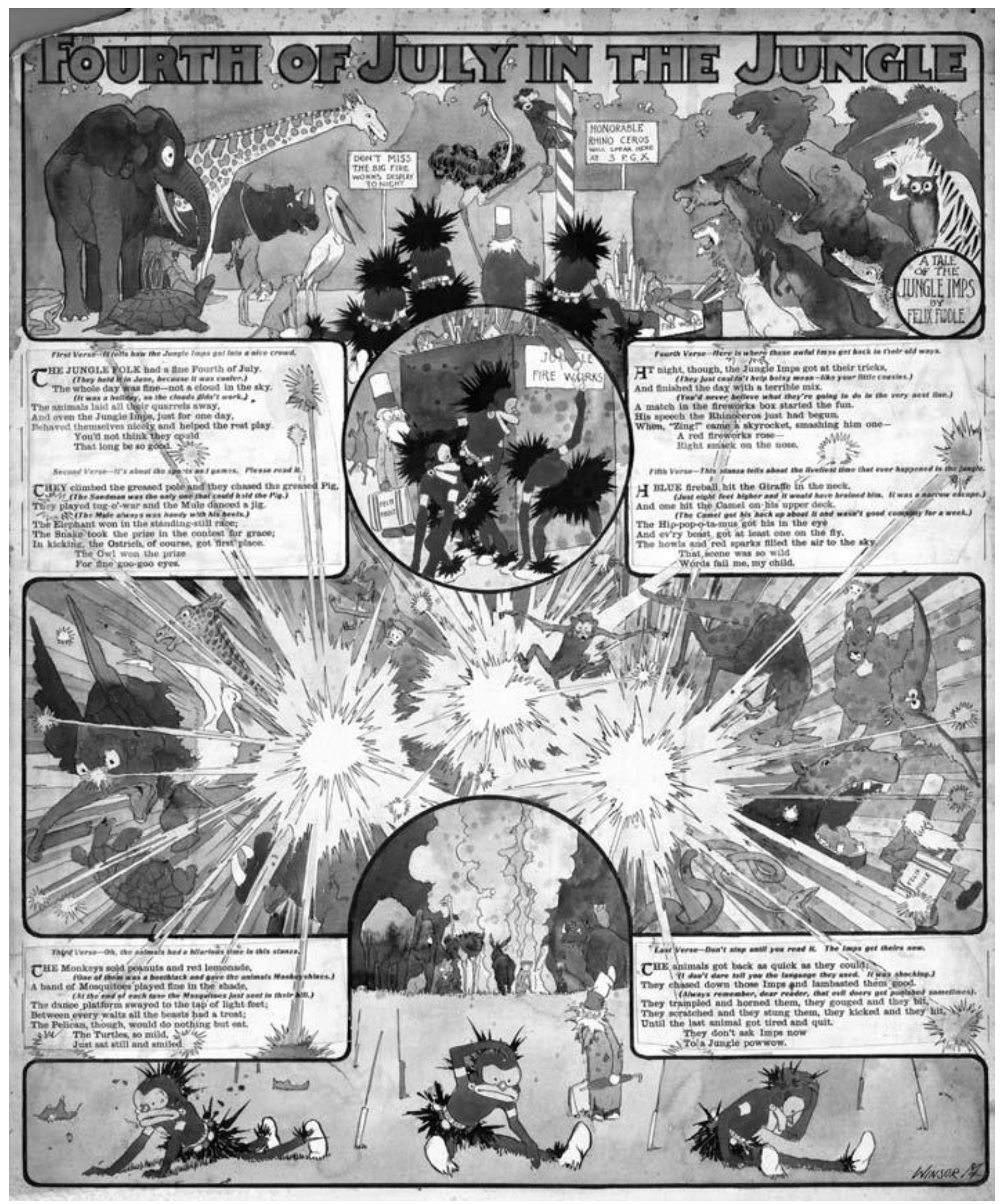




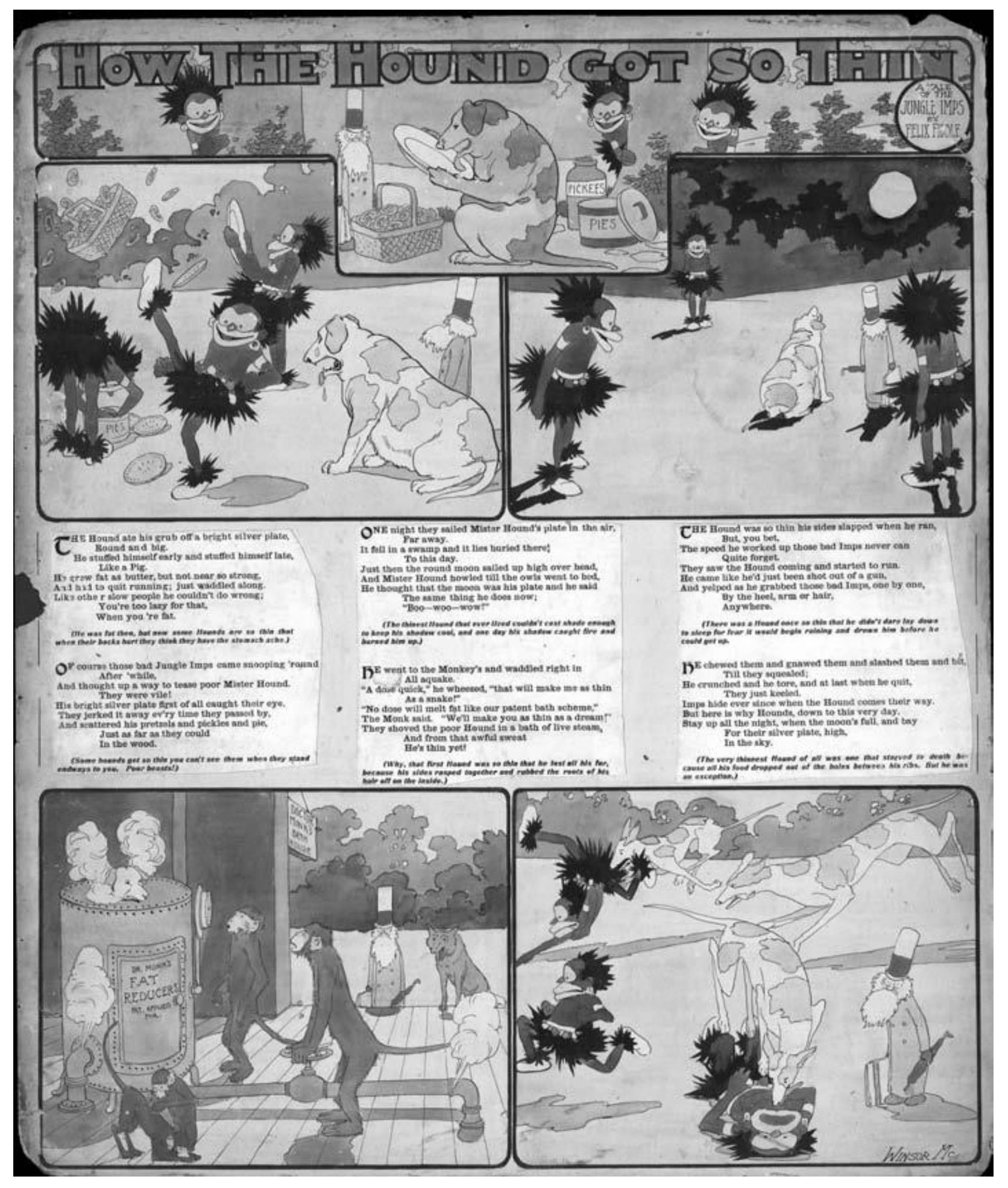

